\title{
Partial Replacement of Cement by Waste Paper Pulp Ash and Its Effect on Concrete Properties
}

\author{
Bahiru Bewket Mitikie (iD) ${ }^{1}$ and Daniel Tekalign Waldtsadik $\mathbb{D}^{2}$ \\ ${ }^{1}$ Adama Science and Technology University, Department of Civil Engineering, Adama 1888, Ethiopia \\ ${ }^{2}$ Debre Brehan University, Department of Construction Technology \& Management, Debre Brehan, Ethiopia \\ Correspondence should be addressed to Daniel Tekalign Waldtsadik; danoss2222@gmail.com
}

Received 28 July 2020; Revised 21 January 2021; Accepted 4 January 2022; Published 1 February 2022

Academic Editor: Satheeskumar Navaratnam

Copyright ( $) 2022$ Bahiru Bewket Mitikie and Daniel Tekalign Waldtsadik. This is an open access article distributed under the Creative Commons Attribution License, which permits unrestricted use, distribution, and reproduction in any medium, provided the original work is properly cited.

\begin{abstract}
An investigation was conducted to study the viability of using waste paper pulp ash as an alternative material applied as a partial replacement of cement in the manufacturing of concrete and its effect on the properties of concrete, and also, the cost and environmental advantage of using waste paper were examined. Four concrete mixes with $0 \%, 5 \%, 10 \%$, and $15 \%$ waste paper pulp ash replacement of OPC and PPC for $25 \mathrm{MPa}$ concrete were prepared. Based on the results obtained from the research, the highest compressive strength obtained at all test ages, i.e., 3, 7, and 28 days, were, 24.36, 28.35, and $36.83 \mathrm{MPa}$, respectively, with $5 \%$ replacement of waste paper pulp ash for OPC, and for PPC, all percentage replacements showed reduction in compressive strength than the control mix. The water absorption of concrete was increased with increasing the percentage of waste paper pulp ash than control concrete. The control concrete clearly has the lowest resistance to $2 \%$ sulfuric acid solution compared to blended concrete of OPC-WPPA and PPC-WPPA. The cost comparison indicates that the incorporation of waste paper pulp ash decreases the cost of concrete and WPPA and saves raw materials used in cement and concrete production.
\end{abstract}

\section{Introduction}

The construction industry is far and wide advanced from day to day. Nowadays, the needs of construction materials are increasing in large amount; cement, aggregates, and water are the three basic components of concrete and the most widely used construction material in the world. The most expensive and very essential material in the production of concrete is cement than all other concrete-making materials, and it is an environmentally unfriendly material. The main environmental challenge faced by the cement industry is release of air $[1,2]$.

In developing countries such as Ethiopia, where different projects for industrialization in conjunction with rapid urbanization are strongly started upon to improve the standard of living, the increase in generation of domestic and industrial wastes is the major problem of environmental pollution. The discarding of wastes has become a major problem in Ethiopia, and among different wastes, paper and paper products are the major wastes [3]. The sources of waste papers are offices, business areas, higher-educational institutions, etc.

The ecosystem is affected by wastes released into the environment. Among all, waste paper is the major source of waste that will affect the environment. In Ethiopia, a sufficient amount of waste papers gos unused, end up in a landfill or dumpsites, and incinerated rather than recycled, thus causing environmental problems by polluting the air, water, and land. Waste paper is available in the environment from different sources, such as office, newspaper, higher educational institutions, and markets.

Large quantities of paper were used by higher-educational institutions for students' assessment each year. In Ethiopia, about 35,000 reams of paper are burnt in each of the institutions per year rather than recycled [4]. Total paper production is 186,000 tons per year, the import is 298,000 
tons per year, export is 1,000 tons per year, consumption is 483,000 tons per year, and total per capita consumption of paper is around $4 \mathrm{~kg}$ per year per person. An increase in per capita consumption of paper is expected with the predictable increase in learning rate and a developing economy [5]. Paper is a recyclable material that, after reaching the garbage dumps, has a degradation period of 3-12 months [6].

Waste is defined as unneeded or unwanted or unuseful byproducts produced during the production of a certain product or the product itself after a certain time span. Other than pollution, waste has no contribution to the environment. Recycling or reusing waste products into other products is environmentally friendly and also has cost-effective advantages for societies [7, 8].

Papercrete and fibrous cement is produced by replacing cement by waste paper. The waste paper was processed to obtain the raw materials of papercrete and fibrous cement. The proportion is a mixture of waste paper pulp, sand, cement, and water by replacing the cement with waste paper pulp at a certain percentage [9].

In Ethiopia, waste papers end up in a landfill or dumpsites and incinerated, and millions of people in the county live in a substandard poorly constructed house or have no housing at all. With the utilization of waste paper, we can solve some of those problems. We can use waste paper as a valuable construction material, rather than throwing it into landfills or dumpsites and incinerating. This is the opportunity to reduce waste and create a new manufacturing industry in the village, creating jobs and a product that could be used across the nation. The product is also highly sustainable and, hence, reduces cement consumption, and carbon dioxide emissions can be captured by using waste as the main raw material and in cement production.

The consumption of natural resources, the quantity of expensive cement, environmental pollution, the number of disposal costs, the effect on the life span of concrete structures and infrastructure, energy challenges for the construction industry, $\mathrm{CO}_{2}$ emissions, denser cement concrete structures, and durability effect can be reduced by using waste paper as cement replacement material [10].

The reviewed studies or research conducted in different countries on the use of paper sludge or mill pulp or hyposludge from the paper industries in concrete and waste paper pulp as papercrete material were investigated as an alternative to landfill disposal in concrete manufacturing as a new recycled material. Even though there is a large amount of waste paper, there no literature or studies exist to explain the suitability and effectiveness of replacing waste paper pulp ash partially with OPC or PPC on the properties of concrete which are conducted in Ethiopia. Based on these gaps, the current study was designed to identify the chemical composition and physical properties of waste paper pulp ash, to observe the effects on the properties of waste paper pulp ash blended cement, and to study the workability, compressive strength, water absorption, and acid resistance of concretes containing waste paper pulp ash.

\section{Materials and Methods}

\subsection{Waste Paper}

2.1.1. Waste Paper Collection. In the research, waste paper is the main constituent material. The type of waste papers used was only white office papers used for writing and printing purposes, and the sources were offices and business areas.

2.1.2. Pulp Preparation. To obtain the waste paper pulp, the waste paper processes in sequence steps were shredded manually into small pieces and then soaked in tap water at room temperature for 3 days. The soaked papers were mixed by hand mixing and using an onion chopper machine until slurry was obtained, and then, the slurry was dewatered until excess water was drained. A waste paper pulp in wet state is obtained after these processes. The wet pulps were dried in an oven at $105^{\circ} \mathrm{C}$ for $24 \mathrm{hrs}$.

2.1.3. Waste Paper Pulp Ash Formation. A process of thermal activation provides waste paper mill sludge ash with pozzolanic properties in the range of temperatures between $500^{\circ} \mathrm{C}$ and $1000^{\circ} \mathrm{C}$, with retention times in the furnace between 2 and 5 hours. The paper mill sludge calcined at $500^{\circ} \mathrm{C}$ for 2 hours is composed of talc, kaolinite, illite, dolomite, calcite, and quartz [11]. In this research, the waste paper pulp was calcined in a furnace at $500^{\circ} \mathrm{C}$ for $2 \mathrm{hrs}$ by cleaning carefully the empty crucibles. After calcination, it is cooled slightly and then placed in a metal plate. When cooled to room temperature, the ashing is weighed on the balance and the calcination temperature was checked by preparation of a pretest for compressive strength of concrete containing 5\% waste paper pulp ash.

\subsubsection{Pretest to Determine Calcination Temperature and} Time. The pretest was conducted for waste paper pulp ash calcined at $500^{\circ} \mathrm{C}$ for 2 hours by casting concrete for control mix and concrete containing 5\% waste paper pulp ash for 3 , 7 , and 28 days. Table 1 shows it clearly about OPC-WPPA0 and with $5 \%$.

The pretest results in the $3^{\text {rd }}, 7^{\text {th }}$, and $28^{\text {th }}$ days of concrete containing $5 \%$ waste paper pulp ash calcined at $500^{\circ} \mathrm{C}$ temperature for $2 \mathrm{hrs}$ were greater than those of control mix, or there was improvement in strength. Therefore, ashing all the dried waste paper pulp were carried out by calcinations in a furnace at a temperature of $500^{\circ} \mathrm{C}$ for $2 \mathrm{hrs}$. It was cooled by air-dried cooling and packed in sacks. An investigation was conducted on its physical and chemical properties.

2.1.5. Ash Determination. The ash content of waste paper pulp was determined; one kilogram of office waste paper pulp gives $0.35 \mathrm{~kg}$ of waste paper pulp ash. Therefore, the ash content was calculated as follows [11]:

$$
\text { Ash, } \%=\frac{A * 100}{B} \text {, }
$$


TABLe 1: Pretest result for compressive strength of C-25 concrete.

\begin{tabular}{|c|c|c|c|c|c|c|c|}
\hline \multicolumn{8}{|c|}{ Average compressive strength } \\
\hline \multirow{2}{*}{ S. no. } & \multirow{2}{*}{ Mix code } & \multicolumn{2}{|r|}{3 days } & \multicolumn{2}{|c|}{7 days } & \multicolumn{2}{|r|}{28 days } \\
\hline & & Load $(\mathrm{kN})$ & Strength $\left(\mathrm{N} / \mathrm{mm}^{2}\right)$ & Load $(\mathrm{kN})$ & Strength $\left(\mathrm{N} / \mathrm{mm}^{2}\right)$ & Load $(\mathrm{kN})$ & Strength $\left(\mathrm{N} / \mathrm{mm}^{2}\right)$ \\
\hline 1 & OPC-WPPA 0 & 275.340 & 12.237 & 448.458 & 19.931 & 660.803 & 29.369 \\
\hline 2 & OPC-WPPA 5 & 343.395 & 15.262 & 536.492 & 23.844 & 714.960 & 31.776 \\
\hline
\end{tabular}

where $A=$ weight of ash $=0.35 \mathrm{~kg} ; B=$ weight of the test sample (moisture free) $=1 \mathrm{~kg}$.

$$
\text { Ash content }(\%)=\frac{0.35 \mathrm{~kg} * 100}{1 \mathrm{~kg}}=35 \% \text {. }
$$

\subsubsection{Physical Properties of Waste Paper Pulp Ash}

(1) Specific Gravity. As shown in Table 2, WPPA has a low specific gravity $\left(2.36 \mathrm{gm} / \mathrm{cm}^{3}\right)$ as compared to OPC and PPC.

(2) Sieve Analysis for Waste Paper Pulp Ash. The grain size distribution of waste paper pulp ash is as shown is Table 3.

(3) Chemical Composition of Waste Paper Pulp Ash. The chemical composition of WPPA was determined in the Ethiopia Geological Survey Laboratory. The most abundant oxides are $\mathrm{SiO}_{2}, \mathrm{Al}_{2} \mathrm{O}_{3}, \mathrm{Fe}_{2} \mathrm{O}_{3}, \mathrm{MgO}, \mathrm{SO}_{3}, \mathrm{Na}_{2} \mathrm{O}, \mathrm{K}_{2} \mathrm{O}, \mathrm{MnO}$, $\mathrm{P}_{2} \mathrm{O}_{5}$, and $\mathrm{TiO}_{2}$, all of which were mainly derived from the burning of waste paper pulp. Currently, there are no specifications to determine the suitability of WPPA for use as a construction material. Nevertheless, the author used ASTM C 618 and Ethiopian Standard [12, 13], which was developed for volcanic ash and coal fly ash use in concrete, to determine the general suitability of WPPA as a potential cement replacement material.

As shown in Table 4, the most predominant constituent of the WPPA sample was calcium oxide $(\mathrm{CaO})$, which was as high as $53.14 \%$. The amount of calcium oxide was higher than classical coal produced Class $\mathrm{C}$ fly ash. The silicon oxide and aluminum oxide were also dominant constituents of the WPPA. The overall ratio of silicon oxide, aluminum oxide, and iron oxide in WPPA was lower than the demand (>70\%) of Class $\mathrm{F}$ fly ash. On the other hand, the $\mathrm{CaO}$ content was high, more than double that usually found in the type $\mathrm{C}$ fly ash. However, its pozzolanic activity is lower, and the WPPA has cementitious properties. The loss on ignition (LOI) value was $6 \%$ for Class $\mathrm{C}$ fly ash and Class F fly ash. However, LOI was relatively higher in WPPA.

Higher calcium fly ash generally exhibits greater hydratable behavior and makes a greater contribution to early strength than obtained from the lower calcium fly ash. Using higher-LOI WSA in concrete will require more air entraining agent [14].

2.2. Cement. The effect of waste paper pulp ash on the properties of concrete was investigated using Dangote's OPC 42.5 and PPC 32.5 cements complying with the requirements of Ethiopian standards.
TABLE 2: Specific gravity of waste paper pulp ash.

\begin{tabular}{lcc}
\hline S. no. & Physical properties & Results $\left(\mathrm{gm} / \mathrm{cm}^{3}\right)$ \\
\hline 1 & Specific gravity & 2.36 \\
\hline
\end{tabular}

TABLE 3: Grain size distribution of waste paper pulp ash.

\begin{tabular}{lc}
\hline Sieve size $(\mu \mathrm{m})$ & Percentage passing of WPPA \\
\hline 150 & 100 \\
125 & 90 \\
75 & 85 \\
63 & 75 \\
\hline
\end{tabular}

\subsection{Aggregates}

2.3.1. Fine Aggregate. The fine aggregate used in the concrete productions is river sand. Among the available river sands in local market, "Dimtu" sand was selected to be used as a fine aggregate throughout the experimental study. The properties of this sand such as silt content, sieve analysis, moisture content, specific gravity, and absorption capacity of fine aggregate were tested to determine the physical properties as shown in Table 5.

2.3.2. Coarse Aggregate. The coarse aggregate with the sizes of $19 \mathrm{~mm}$ was collected from Hawassa monopole crusher sources. The coarse aggregate was washed thoroughly to avoid any unnecessary substances. Then, the aggregate was dried at room temperature on a cleaned surface. In a similar manner like the fine aggregate, laboratory tests were carried out to identify the physical properties of the coarse aggregate. Table 6 shows the physical property of the coarse aggregate.

2.4. Water. In all laboratory work throughout the research, potable clean tap water supplied at the Hawassa University Construction Materials Laboratory was used for both mixing of ingredients and curing of concrete.

2.5. Mix Preparation. To see the effect of waste paper pulp ash on the properties of concrete, the trial mix designs were prepared for concretes made with waste paper pulp ash of $0 \%, 5 \%, 10 \%$, and $15 \%$ percentages. In this research, normal strength concrete C-25 was selected and prepared as per the ACI manual. Four concrete mixes were investigated. The water-to-cement ratio for the mixes containing the waste paper pulp ash was based on preliminary testing to obtain a workable mix as shown in Table 7. 
TABLE 4: Chemical composition of waste paper pulp ash.

\begin{tabular}{cccccccccccc}
\hline $\mathrm{SiO}_{2}$ & $\mathrm{Al}_{2} \mathrm{O}_{3}$ & $\mathrm{Fe}_{2} \mathrm{O}_{3}$ & $\mathrm{CaO}$ & $\mathrm{MgO}$ & $\mathrm{Na}_{2} \mathrm{O}$ & $\mathrm{K}_{2} \mathrm{O}$ & $\mathrm{MnO}$ & $\mathrm{P}_{2} \mathrm{O}_{5}$ & $\mathrm{TiO}_{2}$ & $\mathrm{H}_{2} \mathrm{O}$ & $\mathrm{LOI}$ \\
\hline 6.32 & 1.42 & 0.76 & 53.14 & 0.80 & $<0.01$ & $<0.01$ & $<0.01$ & 0.06 & 0.01 & 0.16 & 38.80 \\
\hline
\end{tabular}

TABLE 5: Summarized physical properties of the fine aggregate.

\begin{tabular}{|c|c|c|c|}
\hline S. no. & \multicolumn{2}{|c|}{ Physical properties } & Results \\
\hline 1 & \multicolumn{2}{|c|}{ Silt content } & $1.63 \%$ \\
\hline \multirow[t]{2}{*}{2} & \multicolumn{2}{|c|}{ Fineness modulus } & 2.62 \\
\hline & & Bulk & 2.58 \\
\hline \multirow[t]{2}{*}{3} & \multirow[t]{2}{*}{ Specific gravity } & Bulk (SSD) & 2.63 \\
\hline & & Apparent & 2.72 \\
\hline 4 & \multicolumn{2}{|c|}{ Absorption capacity } & $2.04 \%$ \\
\hline 5 & \multicolumn{2}{|c|}{ Moisture content } & $2.04 \%$ \\
\hline
\end{tabular}

TABLE 6: Summarized physical properties of the coarse aggregate.

\begin{tabular}{|c|c|c|c|}
\hline S. no. & \multicolumn{2}{|c|}{ Physical properties } & Results \\
\hline & & Bulk & 2.68 \\
\hline \multirow[t]{2}{*}{1} & Specific gravity & Bulk (SSD) & 2.70 \\
\hline & & Apparent & 2.74 \\
\hline 2 & Unit & & $1574 \mathrm{~kg} / \mathrm{m}^{3}$ \\
\hline 3 & Absorptic & pacity & $0.8 \%$ \\
\hline 4 & Moistur & tent & $1.01 \%$ \\
\hline
\end{tabular}

2.6. Specimen Preparation. The materials were batched by weight. First, the cement and waste paper pulp ash were blended together. Then, coarse aggregate, sand, and the blended paste (cement and waste paper pulp ash) were mixed together for a few minutes and stopped. Next, some of the mixing water was added, and then, mixing was started and stopped again. Finally, the rest of the mixing water was added. After all of the ingredients were added, the fresh concrete was mixed for between 3 and 5 minutes of final mixing and until the concrete appears to be homogeneous.

After the mix was carried out, the fresh concrete was then poured into moulds. The cube moulds with internal dimensions of $150 \times 150 \times 150 \mathrm{~mm}$ were used, cleaned, and oiled before casting and compacted using a hand compaction technique. A total of 72 cube specimens for compressive strength, 24 cube specimens for the water absorption test, and 24 cube specimens for the acid test were cast. Therefore, overall, 120 cube specimens were cast to obtain the engineering properties of concrete containing various percentages of waste paper pulp ash.

2.7. Curing. The compacted specimens were demolded after 24 hours, and the hardened cubes were transferred into a curing tank at room temperature. The cubes produced using each of the waste paper pulp ash mix ratios and those of the control mix were removed at the end of the $3^{\text {rd }}, 7^{\text {th }}$, and $28^{\text {th }}$ days from the curing tank.

2.8. Testing Program. The test program was considered the cast concrete specimen of the cube. For testing, before placing the test specimens centrally in the testing machine, any excess moisture from the surface of the specimen was air-dried for between 2 and 20 hours; according to the work in [15], it took 2 hrs for 3 days curing, 6 hrs for 7 days curing, and $20 \mathrm{hrs}$ for 28 days curing. Then, three specimens were tested for the compressive strength, water absorption, and the acid test of concrete containing waste paper pulp ash and control mix.

2.9. Environment-Related Issues. Literature, visual observations, and collected photographs of waste paper damped and incineration areas were utilized to analyze the environmental effect related to waste paper.

\section{Results and Discussion}

The consistency and setting time of the blended pastes of waste paper pulp ash and cement at $0 \%, 5 \%, 10 \%$, and $15 \%$ replacement of cement contents, the workability, compressive strength, density, water absorption and acid resistance, cost comparison of concrete containing waste paper pulp ash at various percentages replacement, and environmental advantage of using waste paper were analyzed and discussed.

3.1. Consistency of Blended Pastes. The normal consistency of blended pastes containing waste paper pulp ash and both OPC and PPC cement is shown in Table 8.

The normal consistency for blended pastes of OPCWPPA and PPC-WPPA shows a small increment as a percentage of replacement of WPPA increase compared to the control paste, and the results were within the usual range of normal consistency of cement paste between $26 \%$ and $33 \%$ [16]. The paste containing waste paper pulp ash requires more water than control paste or paste without waste paper pulp ash. This is because of its porosity as compared to that of cement.

3.2. Setting Time of Blended Pastes. The initial and final setting time of both OPC-WPPA and PPC-WPPA blended paste were determined and shown in Table 9.

Increasing the percentage content of the WPPA replacement in both OPC-WPPA and PPC-WPPA concrete mixture decreases both the initial and final setting times as compared to the control concrete. This may be due to three reasons [13]. Firstly, waste paper pulp ash absorbed more water as compared to cement. The high water absorption of WPPA particles may accelerate the hydration reaction. Therefore, the time needed to set was accelerated. Secondly, the concentration of gypsum (contained in the cement) in the mixture became lower by increasing the WPPA replacement. Consequently, rapid times of setting may occur. Thirdly, the comparatively higher content of $\mathrm{CaO}$ in WPPA may further influence the hydration process. 
Table 7: Mix Proportions for OPC-WPPA and PPC-WPPA of C-25 concretes.

\begin{tabular}{|c|c|c|c|c|c|c|c|c|}
\hline S. no. & Mix code & Cement type & Cement quantity (kg) & $\begin{array}{c}\text { Waste } \\
\text { paper pulp } \\
\text { ash (kg) }\end{array}$ & Water $(\mathrm{kg})$ & FA $(\mathrm{kg})$ & CA (kg) & $\mathrm{W} / \mathrm{C}$ \\
\hline 1 & OPC-WPPAO & OPC & 17.42 & $\mathbf{0}$ & 10.53 & 46.98 & 56.34 & 0.61 \\
\hline 2 & OPC-WPPA5 & $\mathrm{OPC}$ & 16.549 & 0.871 & 10.53 & 46.98 & 56.34 & 0.61 \\
\hline 3 & OPC-WPPA10 & OPC & 15.678 & 1.742 & 10.53 & 46.98 & 56.34 & 0.61 \\
\hline 4 & OPC-WPPA15 & OPC & 14.807 & 2.613 & 10.53 & 46.98 & 56.34 & 0.61 \\
\hline 5 & PPC-WPPA0 & PPC & 17.42 & $\mathbf{0}$ & 10.53 & 46.98 & 56.34 & 0.61 \\
\hline 6 & PPC-WPPA5 & PPC & 16.549 & 0.871 & 10.53 & 46.98 & 56.34 & 0.61 \\
\hline 7 & PPC-WPPA10 & PPC & 15.678 & 1.742 & 10.53 & 46.98 & 56.34 & 0.61 \\
\hline 8 & PPC-WPPA15 & PPC & 14.807 & 2.613 & 10.53 & 46.98 & 56.34 & 0.61 \\
\hline
\end{tabular}

Bold values are the controlling mix ( $0 \%$ paper ash).

TABLE 8: Normal consistency of blended pastes of OPC-WPPA and PPC-WPPA.

\begin{tabular}{llc}
\hline S. no. & Mix code & Consistency \\
\hline $\mathbf{1}$ & OPC-WPPA0 & $\mathbf{2 9}$ \\
2 & OPC-WPPA5 & 30 \\
3 & OPC-WPPA10 & 31.2 \\
4 & OPC-WPPA15 & 32.4 \\
$\mathbf{5}$ & PPC-WPPA0 & $\mathbf{2 7 . 5}$ \\
6 & PPC-WPPA5 & 29.5 \\
7 & PPC-WPPA10 & 30.5 \\
8 & PPC-WPPA15 & 31.5 \\
\hline
\end{tabular}

Bold shows demarcation with controlling mix.

TABLE 9: Setting time of blended pastes of OPC-WPPA and PPC-WPPA.

\begin{tabular}{lccc}
\hline S. no. & Mix code & $\begin{array}{c}\text { Initial setting time } \\
\text { (minutes) }\end{array}$ & $\begin{array}{c}\text { Final setting time } \\
\text { (minutes) }\end{array}$ \\
\hline $\mathbf{1}$ & OPC-WPPA0 & $\mathbf{1 7 0}$ & $\mathbf{2 9 0}$ \\
2 & OPC-WPPA5 & 150 & 270 \\
3 & OPC-WPPA10 & 122 & 225 \\
4 & OPC-WPPA15 & 115 & 220 \\
$\mathbf{5}$ & PPC-WPPA0 & 273 & $\mathbf{3 9 0}$ \\
6 & PPC-WPPA5 & 244 & 365 \\
7 & PPC-WPPA10 & 236 & 360 \\
8 & PPC-WPPA15 & 227 & 340 \\
\hline
\end{tabular}

Bold shows controlling mix for OPC and PPC.

\subsection{Properties of Fresh Concrete}

3.3.1. Workability of Concrete Containing Waste Paper Pulp Ash. The workability evaluation of OPC-WPPA and PPCWPPA mixtures is presented in Table 10. As seen, the slump value of blended pastes decreased with increase in the WPPA content.

The slump value of all mixtures decreased with the increase of waste paper pulp ash content. Waste paper pulp ash absorbed more water as compared to cement and, thus, had decreasing slump value, but the results obtained were within the predetermined slump range of $25-50 \mathrm{~mm}$.

Several factors could lead to adverse effects on the workability of waste paper concrete. The amount of paper replacement, waste paper physical properties, and the carbon content of the waste paper would be the main reasons for the reduction of concrete workability [17].
TABle 10: Slump test results of OPC-WPPA and PPC-WPPA.

\begin{tabular}{llc}
\hline S. no. & Mix code & Slump $(\mathrm{mm})$ \\
\hline $\mathbf{1}$ & OPC-WPPA 0 & $\mathbf{3 5}$ \\
2 & OPC-WPPA 5 & 31 \\
3 & OPC-WPPA10 & 29 \\
4 & OPC-WPPA15 & 26 \\
$\mathbf{5}$ & PPC-WPPA 0 & 36 \\
6 & PPC-WPPA 5 & 32 \\
7 & PPC-WPPA10 & 28 \\
8 & PPC-WPPA15 & 25 \\
\hline
\end{tabular}

Bold shows control mix.

3.4. Properties of Hardened Concrete. In this part, the strength (compressive strength), density, and durability (water absorption and acid resistance) properties of the hardened concrete containing waste paper pulp ash were analyzed and discussed.

3.4.1. Compressive Strength of Concrete Containing Waste Paper Pulp Ash. The average compressive strength test results for OPC-WPPA and PPC-WPPA concrete mix are shown in Table 11.

The compressive strength test result of OPC-WPPA increasing in compressive strength was observed at 5\% replacement of cement by waste paper pulp ash than control mix (0\%). The compressive strength of the concrete mix of OPCWPPA with $10 \%$ and $15 \%$ replacement was found to be less than that of control mix (0\%). This can indicate that waste paper pulp ash is capable of replacing up to $5 \%$ of ordinary Portland cement (OPC) by weight. For PPC-WPPA concrete mixes, the compressive strength test result obtained shows decrease in compressive strength by $5 \%, 10 \%$, and $15 \%$ replacement of cement by waste paper pulp ash than control mix (0\%). The reduction of compressive strength with increasing the replacement of waste paper pulp ash is due to the high replacement of cement by waste paper pulp ash, thus reducing cement which causes reduction of hydration reaction.

3.4.2. Density of Concrete Containing Waste Paper Pulp Ash. The density of each concrete cubes was determined by dividing the mass cubes, after their removal from the curing tank before testing them for the compressive strength, by its volume. In this part, the density of the concrete was 
TABLE 11: Compressive strength of OPC-WPPA and PPC-WPPA concrete.

\begin{tabular}{|c|c|c|c|c|c|c|c|}
\hline \multirow{3}{*}{ S. no. } & \multirow{3}{*}{ Mix code } & \multicolumn{6}{|c|}{ Average compressive strength } \\
\hline & & \multicolumn{2}{|c|}{3 days } & \multicolumn{2}{|c|}{7 days } & \multicolumn{2}{|c|}{28 days } \\
\hline & & Load $(\mathrm{kN})$ & Strength $(\mathrm{MPa})$ & Load $(\mathrm{kN})$ & Strength $(\mathrm{MPa})$ & Load $(\mathrm{kN})$ & Strength $(\mathrm{MPa})$ \\
\hline 1 & OPC-WPPAO & 521.219 & 23.165 & 590.960 & 26.265 & 778.035 & 34.579 \\
\hline 2 & OPC-WPPA5 & 548.01 & 24.356 & 637.832 & 28.348 & 828.603 & 36.827 \\
\hline 3 & OPC-WPPA10 & 501.064 & 22.270 & 553.459 & 24.598 & 719.459 & 31.976 \\
\hline 4 & OPC-WPPA15 & 390.813 & 17.370 & 487.644 & 21.673 & 606.020 & 26.934 \\
\hline 5 & PPC-WPPA0 & 386.822 & 17.192 & 448.335 & 19.926 & 670.890 & 29.818 \\
\hline 6 & PPC-WPPA5 & 368.035 & 16.357 & 436.584 & 19.404 & 609.541 & 27.091 \\
\hline 7 & PPC-WPPA10 & 355.271 & 15.789 & 426.142 & 18.940 & 596.148 & 26.496 \\
\hline 8 & PPC-WPPA15 & 351.652 & 15.621 & 423.941 & 18.842 & 518.978 & 23.066 \\
\hline
\end{tabular}

Bold shows control mix.

calculated for 28 days weight, and the results are as shown in Table 12.

The density decreases with the increase in waste paper pulp ash content. The reduction in the density of concrete containing waste paper pulp ash shows lesser specific gravity of waste paper pulp ash $\left(2.36 \mathrm{gm} / \mathrm{cm}^{3}\right)$ as compared to $3.15 \mathrm{gm} / \mathrm{cm}^{3}$ for OPC and $2.9 \mathrm{gm} / \mathrm{cm}^{3}$ for PPC. Therefore, waste paper pulp ash concrete is light in weight.

\subsubsection{Water Absorption of Concrete Containing Waste Paper} Pulp Ash. The concrete water absorption test is the means of durability evaluation. The cube specimens after 28 days curing were then oven-dried for 24 hours at the temperature of $105-110^{\circ} \mathrm{C}$ and weighed, and the average dry weight of cubes (W1) was calculated. After that, the specimens were kept in water for 24 hours. Then, they were weighed, and the average wet weight of cube specimens (W2) was calculated [18]. The percentage of water absorption is shown in Table 13.

The percentage of water absorption for both OPCWPPA and PPC-WPPA mixtures increased with an increase in waste paper pulp ash content.

\subsubsection{Acid Resistance of Concrete Containing Waste Paper Pulp Ash}

(1) Mass Loss. The mass loss of cube specimens was determined after 28 days curing in $2 \%$ sulfuric acid solution and calculated as follows:

The Mass Loss (ML) of cube specimens $=\frac{W_{r}-W_{s}}{W_{r}} * 100$,

where $W_{r}=$ is the average initial weight in grams of three specimens before immersion in the acid solution; $W_{s}=$ is the average weight in grams of three specimens after immersed in an acid solution for the required period of time.

The maximum mass loss occurred from both OPCWPPA and PPC-WPPA concrete mixes in $0 \%$ cement replacement. OPC-WPPA with 5\% and 10\% replacement observed a mass loss, and they were the second and third largest mass loss observed mixes, respectively. The minimal mass loss was observed in mix OPC-WPPA with 15\%
Table 12: Density of OPC-WPPA and PPC-WPPA concrete.

\begin{tabular}{lccc}
\hline S. no. & Mix code & Density $\left(\mathrm{gm} / \mathrm{cm}^{3}\right)$ & Reduction $(\%)$ \\
\hline $\mathbf{1}$ & OPC-WPPA0 & $\mathbf{2 . 4 2 3}$ & $\mathbf{0 . 0 0}$ \\
2 & OPC-WPPA5 & 2.392 & 1.296 \\
3 & OPC-WPPA10 & 2.389 & 1.423 \\
4 & OPC-WPPA15 & 2.379 & 1.850 \\
$\mathbf{5}$ & PPC-WPPA0 & $\mathbf{2 . 4 0 1}$ & $\mathbf{0 . 0 0}$ \\
6 & PPC-WPPA5 & 2.390 & 1.10 \\
7 & PPC-WPPA10 & 2.387 & 1.40 \\
8 & PPC-WPPA15 & 2.386 & 1.50 \\
\hline
\end{tabular}

Bold shows control mix.

replacement, which provides a higher resistance to sulfuric acid attack. This indicates the PPC-WPPA concrete mix with $15 \%$ replacement has a higher resistance to $2 \%$ sulfuric acidic environment. The results are summarized in Table 14.

The reduction of the large capillary and somehow blocking of these pores which is caused by the formation of secondary $\mathrm{C}-\mathrm{S}-\mathrm{H}$ through a pozzolanic reaction that refines the pore structure play a critical role in protecting concrete against ingression of harmful chemicals. The $\mathrm{C}_{3} \mathrm{~A}$ of cement, which is the most vulnerable to the intrusion of sulfate ions and responsible for secondary ettringite formation, and the amount of $\mathrm{Ca}(\mathrm{OH})_{2}$ content are reduced by the incorporation of supplementary cementation materials [19]. Therefore, increasing the quantity of waste paper pulp ash in replacement of cement has been beneficial with regards to the Mass Loss (MS) of concrete specimens subjected to severe sulfuric acid solution. WPPA reduces the deterioration of concrete immersed in sulfuric acid.

(2) Compressive Strength Loss. The compressive strength loss (CSL) was calculated as follows [19]:

$$
\mathrm{CSL}=\frac{f_{c r}-f_{c s}}{f_{c r}} * 100,
$$

where $f_{c r}=$ is the reference compressive strength of cube specimens in MPa before immersion in the acid solution; $f_{c s}=$ is the average compressive strength of cube specimens in $\mathrm{MPa}$ after immersed in acid solution for the required period of time.

In Table 15, OPC-WPPA and PPC-WPPA concrete mix $0 \%$ replacement of cement had the highest loss in compressive strength. Concrete mix OPC-WPPA with 5\% and 
TABLE 13: Water absorption test results of OPC-WPPA and PPC-WPPA concrete after 28 days of curing.

\begin{tabular}{|c|c|c|c|c|c|}
\hline S. no. & Mix code & Av. dry weight of cube (gm) (W1) & Av. wet weight of cube (gm) (W2) & $\begin{array}{c}\text { Water absorbed (gm) } \\
(\mathrm{W} 2-\mathrm{W} 1)\end{array}$ & $\begin{array}{c}\text { Percentage water } \\
\text { absorption }\end{array}$ \\
\hline 1 & OPC-WPPAO & 8193.33 & 8313.33 & 120 & 1.46 \\
\hline 2 & OPC-WPPA5 & 8023.33 & 8180 & 156.67 & 1.95 \\
\hline 3 & $\begin{array}{c}\text { OPC- } \\
\text { WPPA10 }\end{array}$ & 7950 & 8143.33 & 193.33 & 2.43 \\
\hline 4 & $\begin{array}{c}\text { OPC- } \\
\text { WPPA15 }\end{array}$ & 7863.33 & 8103.33 & 240 & 3.05 \\
\hline 5 & PPC-WPPAO & 8116.67 & 8226.67 & 110 & 1.36 \\
\hline 6 & PPC-WPPA5 & 8006.67 & 8173.33 & 146.67 & 1.83 \\
\hline 7 & PPC-WPPA10 & 7963.33 & 8146.67 & 183.33 & 2.30 \\
\hline 8 & PPC-WPPA15 & 7900 & 8126.67 & 226.67 & 2.87 \\
\hline
\end{tabular}

Bold shows control mix.

TABLE 14: Mass loss of OPC-WPPA and PPC-WPPA concrete cured under 2\% sulfuric acid.

\begin{tabular}{lcccc}
\hline S. no. & Mix code & Weight before immersion $\left(W_{r}\right)$ in gm & Weight after immersion $\left(W_{s}\right)$ in gm & Mass loss $($ MS) in \% \\
\hline $\mathbf{1}$ & OPC-WPPA0 & $\mathbf{8 2 5 0}$ & $\mathbf{8 2 3 6 . 6 7}$ & $\mathbf{0 . 2 8 3}$ \\
2 & OPC-WPPA5 & 8163.33 & 8146.67 & 0.204 \\
3 & OPC-WPPA10 & 8136.67 & 8090 & 0.164 \\
4 & OPC-WPPA15 & 8120 & 8076.67 & 0.123 \\
$\mathbf{5}$ & PPC-WPPA0 & $\mathbf{8 1 5 6 . 6 7}$ & $\mathbf{8 1 4 6 . 6 7}$ & $\mathbf{0 . 3 2 7}$ \\
6 & PPC-WPPA5 & 8146.67 & 8126.67 & 0.246 \\
7 & PPC-WPPA10 & 8136.67 & 8110 & 0.204 \\
8 & PPC-WPPA15 & 8123.33 & 0.164 & \\
\hline
\end{tabular}

Bold shows control mix.

$10 \%$ cement replacement showed the second and third largest compressive strength loss. The concrete mix OPCWPPA with $15 \%$ cement replacement also showed a minimal change compressive strength loss trend. This indicates the concrete mix with $15 \%$ cement replacement is not severe in the $2 \%$ sulfuric acidic environment.

Concrete that contains supplementary cementing materials has lower C/S ratio than concrete with $100 \%$ Portland cement, which protects the cement paste from deterioration. In a low-pH acidic environment, the $\mathrm{C}-\mathrm{S}-\mathrm{H}$ releases most of its lime while a layer that consists of silica and alumina silicate gels remains and protects the cement paste from further corrosion [1]. Therefore, one of the primary reasons behind the improved resistance of the concrete samples that contain waste paper pulp ash could be the production of $\mathrm{C}-\mathrm{S}-\mathrm{H}$ with a lower $\mathrm{C} / \mathrm{S}$ ratio.

In $0 \%$ replacement concrete mixes, a high $\mathrm{C} / \mathrm{S}$ ratio, the dissolution of $\mathrm{Ca}(\mathrm{OH})_{2}$ and calcium sulphoaluminates, and the decalcification of $\mathrm{C}-\mathrm{S}-\mathrm{H}$ will result in the formation of a porous degraded layer vulnerable to more acid attacks, while in concrete that contains waste paper pulp ash, due to lower $\mathrm{C} / \mathrm{S}$ ratio, a dense silica gel layer will form, which protects the cement paste from more deterioration.

(3) Visual Inspection. The performance of the concrete specimens with regards to resistance against severe sulfuric attack can be compared and examined by visual inspection. The specimens were removed from the solutions carefully for the performance evaluations. Figures 1 and 2 show the
OPC-WPPA and PPC-WPPA concrete mix exposed in $2 \%$ sulfuric acid solution. It can be seen that $0 \%$ mixes suffered the greatest signs of deterioration at the end of 28 days in comparison to the other mixes. Mixes $5 \%$ and $10 \%$ also showed the signs of deterioration. Mixes $15 \%$ showed similar behavior. However, the deterioration signs were less as compared to other replacements of waste paper pulp ash. Visual inspection of the specimens of the concrete mixes indicates that the protective layer still exists. It is suspected that the protective layer is weaker of the concrete with $0 \%$. The lower performance of the concrete samples was obtained with $0 \%$ replacement, while $5 \%, 10 \%$, and $15 \%$ were in a better condition.

\subsection{Cost Comparison of Concrete Containing Waste Paper Pulp Ash and Control Mix}

3.5.1. The Cost Comparison for OPC-WPPAO and PPCWPPA0. The cost comparison for $1 \mathrm{~m}^{3}$ of OPC-WPPA and PPC-WPPA concrete with $0 \%$ replacement was calculated and shown in Table 16.

3.5.2. The Cost Comparison for OPC-WPPA5 and PPCWPPA5. The cost comparison for $1 \mathrm{~m}^{3}$ of OPC-WPPA and PPC-WPPA concrete with 5\% replacement was calculated, and the percentage of cost reduction for both mixes is shown in Table 17. 
TABLE 15: Compressive strength loss (CSL) of OPC-WPPA and PPC-WPPA concrete cured in 2\% sulfuric acid solution.

\begin{tabular}{|c|c|c|c|c|}
\hline $\begin{array}{l}\text { S. } \\
\text { no. }\end{array}$ & Mix code & $\begin{array}{c}\text { Average compressive strength } \\
\text { before } \\
\text { immersion in } \mathrm{MPa} \\
\end{array}$ & $\begin{array}{l}\text { Average compressive strength after immersion } \\
\text { in } \mathrm{MPa}\end{array}$ & $\begin{array}{c}\text { Compressive strength loss (CSL) } \\
\text { in } \%\end{array}$ \\
\hline 1 & $\begin{array}{l}\text { OPC- } \\
\text { WPPA0 }\end{array}$ & 34.579 & 31.571 & 8.825 \\
\hline 2 & $\begin{array}{c}\text { OPC- } \\
\text { WPPA5 }\end{array}$ & 36.827 & 33.586 & 8.424 \\
\hline 3 & $\begin{array}{l}\text { OPC- } \\
\text { WPPA10 }\end{array}$ & 31.976 & 31.128 & 2.587 \\
\hline 4 & $\begin{array}{c}\text { OPC- } \\
\text { WPPA15 }\end{array}$ & 26.934 & 26.503 & 1.526 \\
\hline 5 & $\begin{array}{l}\text { PPC- } \\
\text { WPPA0 }\end{array}$ & 29.818 & 27.499 & 7.791 \\
\hline 6 & PPC-WPPA5 & 27.091 & 24.996 & 7.720 \\
\hline 7 & $\begin{array}{c}\text { PPC- } \\
\text { WPPA10 }\end{array}$ & 26.496 & 24.530 & 7.428 \\
\hline 8 & $\begin{array}{c}\text { PPC- } \\
\text { WPPA15 }\end{array}$ & 23.066 & 21.539 & 6.677 \\
\hline
\end{tabular}

Bold shows control mix.
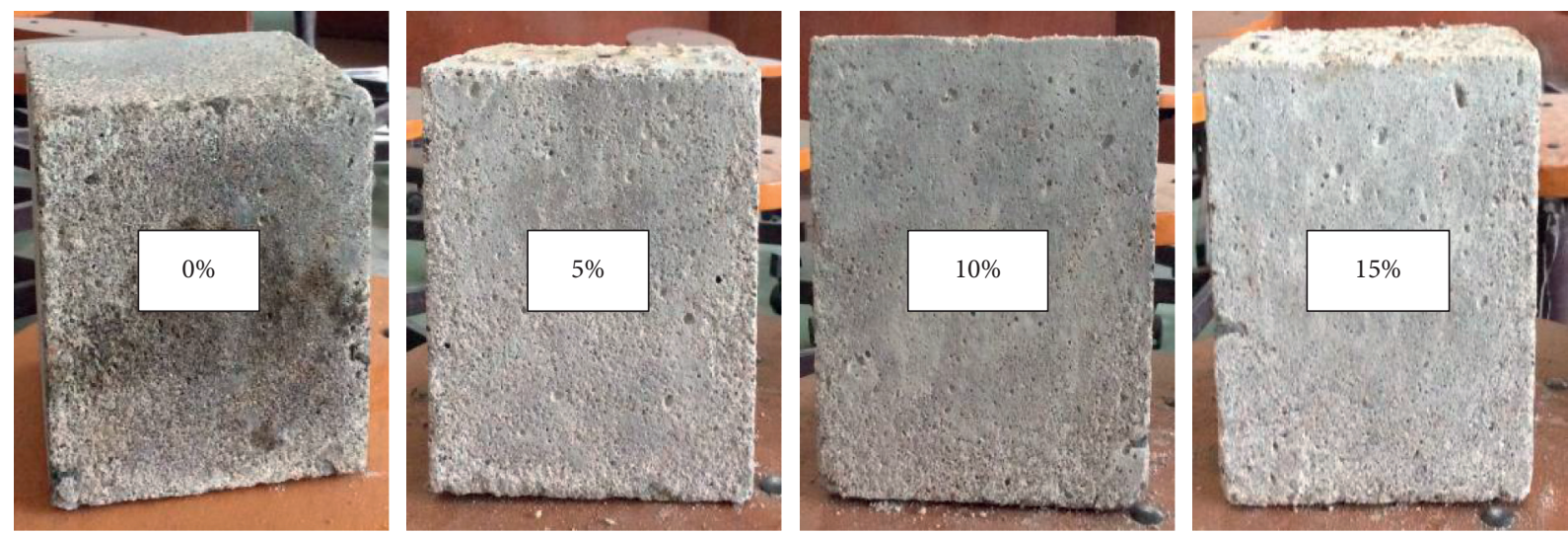

FIGURE 1: OPC-WPPA concrete deterioration in $2 \%$ sulfuric acid solution.
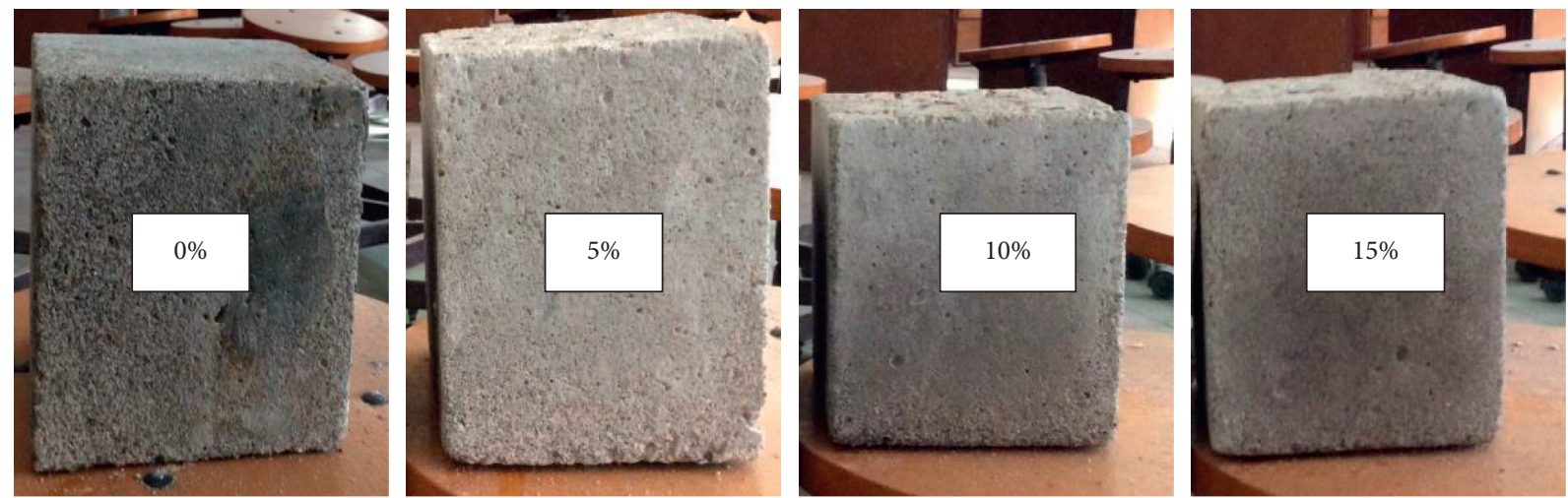

Figure 2: PPC-WPPA concrete deterioration in $2 \%$ sulfuric acid solution.

3.5.3. The Cost Comparison for OPC-WPPA10 and PPCWPPA10. The cost comparison for $1 \mathrm{~m}^{3}$ of OPC-WPPA and PPC-WPPA concrete with $10 \%$ replacement was calculated, and the percentage cost reduction for both mixes is shown in Table 18 .
3.5.4. The Cost Comparison for OPC-WPPA15 and PPCWPPA15. The cost comparison for $1 \mathrm{~m}^{3}$ of OPC-WPPA and PPC-WPPA concrete with 15\% replacement was calculated, and the percentage cost reduction for both mixes is shown in Table 19. 
TABLE 16: OPC-WPPA0 and PPC-WPPA0.

\begin{tabular}{|c|c|c|c|c|c|c|c|c|c|}
\hline Item & \multicolumn{4}{|c|}{ Concrete } & Item & \multicolumn{4}{|c|}{ Concrete } \\
\hline Mix code & \multicolumn{4}{|c|}{ OPC-WPPA 0} & Mix code & \multicolumn{4}{|c|}{ PPC-WPPA 0} \\
\hline Total quantity of item & \multicolumn{4}{|c|}{$1 \mathrm{~m}^{3}$} & Total quantity of item & \multicolumn{4}{|c|}{$1 \mathrm{~m}^{3}$} \\
\hline Type of material & Unit & Qty & Rate (birr) & Cost per unit (birr) & Type of material & Unit & Qty & Rate (birr) & Cost per unit (birr) \\
\hline Cement & Qnt. & 3.11 & 320 & 995.20 & Cement & Qnt. & 3.11 & 260 & 808.6 \\
\hline Sand & $\mathrm{m}^{3}$ & 0.524 & 280 & 146.72 & Sand & $\mathrm{m}^{3}$ & 0.524 & 280 & 146.72 \\
\hline C. aggregate & $\mathrm{m}^{3}$ & 0.629 & 520 & 327.08 & C. aggregate & $\mathrm{m}^{3}$ & 0.629 & 520 & 327.08 \\
\hline Water & $\mathrm{m}^{3}$ & 0.188 & - & - & Water & $\mathrm{m}^{3}$ & 0.188 & - & - \\
\hline Waste paper pulp ash & $\mathrm{kg}$ & - & - & - & Waste paper pulp ash & $\mathrm{kg}$ & - & - & - \\
\hline Total 1 & & & & 1469.00 & & Cotal & & & 1282.40 \\
\hline
\end{tabular}

TABLE 17: OPC-WPPA5 and PPC-WPPA5.

\begin{tabular}{|c|c|c|c|c|c|c|c|c|c|}
\hline \multirow{3}{*}{$\begin{array}{l}\text { Item } \\
\text { Mix code } \\
\text { Total quantity of item }\end{array}$} & \multicolumn{4}{|c|}{ Concrete } & Item & \multicolumn{4}{|c|}{ Concrete } \\
\hline & \multicolumn{4}{|c|}{ OPC-WPPA 5} & Mix code & \multicolumn{4}{|c|}{ PPC-WPPA 5} \\
\hline & \multicolumn{4}{|c|}{$1 \mathrm{~m}^{3}$} & Total quantity of item & \multicolumn{4}{|c|}{$1 \mathrm{~m}^{3}$} \\
\hline Type of material & Unit & Qty & Rate (birr) & Cost per unit (birr) & Type of material & Unit & Qty & Rate (birr) & Cost per unit (birr) \\
\hline Cement & Qnt. & 2.954 & 320 & 945.28 & Cement & Qnt. & 2.954 & 260 & 768.04 \\
\hline Sand & $\mathrm{m}^{3}$ & 0.524 & 280 & 146.72 & Sand & $\mathrm{m}^{3}$ & 0.523 & 280 & 146.72 \\
\hline C. aggregate & $\mathrm{m}^{3}$ & 0.629 & 520 & 327.08 & C. aggregate & $\mathrm{m}^{3}$ & 0.629 & 520 & 327.08 \\
\hline Water & $\mathrm{m}^{3}$ & 0.188 & - & - & Water & $\mathrm{m}^{3}$ & 0.188 & - & - \\
\hline Waste paper pulp ash & $\mathrm{kg}$ & 15.6 & 1.00 & 15.6 & Waste paper pulp ash & $\mathrm{kg}$ & 15.6 & 1.00 & 15.6 \\
\hline Total & & & & 1434.68 & & otal & & & 1257.44 \\
\hline \multicolumn{4}{|c|}{$\begin{array}{l}\text { Total cost reduced by } 5 \% \text { waste paper pulp ash } \\
\text { replacement }(\%)\end{array}$} & 2.34 & \multicolumn{4}{|c|}{$\begin{array}{c}\text { Total cost reduced by } 5 \% \text { waste paper pulp ash } \\
\text { replacement (\%) }\end{array}$} & 1.95 \\
\hline
\end{tabular}

TABle 18: OPC-WPPA 10 and PPC-WPPA 10.

\begin{tabular}{|c|c|c|c|c|c|c|c|c|c|}
\hline Item & & & Concr & & Item & & & Concr & \\
\hline Mix code & & & OPC-WP & PA 10 & Mix code & & & PPC-WPI & PA 10 \\
\hline Total quantity of item & & & $1 \mathrm{~m}^{3}$ & & Total quantity of item & & & $1 \mathrm{~m}^{3}$ & \\
\hline Type of material & Unit & Qty & Rate (birr) & Cost per unit (birr) & Type of material & Unit & Qty & Rate (birr) & Cost per unit (birr) \\
\hline Cement & Qnt. & 2.799 & 320 & 895.68 & Cement & Qnt. & 2.799 & 260 & 727.74 \\
\hline Sand & $\mathrm{m}^{3}$ & 0.524 & 280 & 146.72 & Sand & $\mathrm{m}^{3}$ & 0.524 & 280 & 146.72 \\
\hline C. aggregate & $\mathrm{m}^{3}$ & 0.629 & 520 & 327.08 & C. aggregate & $\mathrm{m}^{3}$ & 0.629 & 520 & 327.08 \\
\hline Water & $\mathrm{m}^{3}$ & 0.188 & - & - & Water & $\mathrm{m}^{3}$ & 0.188 & - & - \\
\hline Waste paper pulp ash & $\mathrm{kg}$ & 31.1 & 1.00 & 31.1 & Waste paper pulp ash & $\mathrm{kg}$ & 31.1 & 1.00 & 31.1 \\
\hline Total & & & & 1400.58 & & Cotal & & & 1232.64 \\
\hline $\begin{array}{l}\text { Total cost reduced by } \\
\text { replacement }(\%)\end{array}$ & $10 \% \mathrm{w}$ & aste pap & er pulp ash & 4.66 & $\begin{array}{r}\text { Total cost reduced by } \\
\text { replac }\end{array}$ & $\begin{array}{l}10 \% \mathrm{w} \\
\text { ment }\end{array}$ & $\begin{array}{l}\text { aste pap } \\
(\%)\end{array}$ & er pulp ash & 3.88 \\
\hline
\end{tabular}

TABLE 19: OPC-WPPA 15 and PPC-WPPA15.

\begin{tabular}{|c|c|c|c|c|c|c|c|c|c|}
\hline Item & \multicolumn{4}{|c|}{ Concrete } & Item & \multicolumn{4}{|c|}{ Concrete } \\
\hline Mix code & \multicolumn{4}{|c|}{ OPC-WPPA 15} & Mix code & \multicolumn{4}{|c|}{ PPC-WPPA 15} \\
\hline Total quantity of item & \multicolumn{4}{|c|}{$1 \mathrm{~m}^{3}$} & Total quantity of item & \multicolumn{4}{|c|}{$1 \mathrm{~m}^{3}$} \\
\hline Type of material & Unit & Qty & Rate (birr) & Cost per unit (birr) & Type of material & Unit & Qty & Rate (birr) & Cost per unit (birr) \\
\hline Cement & Qnt. & 2.643 & 320 & 845.76 & Cement & Qnt. & 2.643 & 260 & 687.18 \\
\hline Sand & $\mathrm{m}^{3}$ & 0.524 & 280 & 146.72 & Sand & $\mathrm{m}^{3}$ & 0.524 & 280 & 146.72 \\
\hline C. aggregate & $\mathrm{m}^{3}$ & 0.629 & 520 & 327.08 & C. aggregate & $\mathrm{m}^{3}$ & 0.629 & 520 & 327.08 \\
\hline Water & $\mathrm{m}^{3}$ & 0.188 & - & - & Water & $\mathrm{m}^{3}$ & 0.188 & - & - \\
\hline Waste paper pulp ash & $\mathrm{kg}$ & 46.7 & 1.00 & $\begin{array}{c}46.7 \\
1366.26\end{array}$ & Waste paper pulp ash & $\mathrm{kg}$ & 46.7 & 1.00 & $\begin{array}{c}46.7 \\
1207.68\end{array}$ \\
\hline \multicolumn{4}{|c|}{$\begin{array}{l}\text { Total cost reduced by } 15 \% \text { waste paper pulp ash } \\
\text { replacement }(\%)\end{array}$} & 6.99 & \multicolumn{4}{|c|}{$\begin{array}{l}\text { Total cost reduced by } 15 \% \text { waste paper pulp ash } \\
\text { replacement }(\%)\end{array}$} & 5.83 \\
\hline
\end{tabular}


The cost of waste paper pulp ash is negligible, since it is a waste material. The cost comparison indicates that the incorporation of waste paper pulp ash decreases the cost of concrete. Thus, it has been established that, to some extent, the use of waste paper in concrete can save the disposal costs and can produce a greener concrete for construction. Finally, it was found that the OPC-WPPA concrete mix with 5\% partial replacement of cement by waste paper pulp ash reduces the cost of concrete by $2.34 \%$ with equivalent concrete properties such as consistency, workability, compressive strength, absorption, and resistance to $2 \%$ sulfuric acid solution compared to control concrete.

3.6. Environmental Effects of Waste Paper and Cement Production. Cost economy, energy efficiency, durability, and overall ecological profile of concrete benefit would be obtained by replacing cement with waste materials. Therefore, in the future, the use of waste materials as supplementary cementing materials ought to be made mandatory. Among wastes, paper is one of waste material. Waste paper can reduce the use of manufactured Portland cement clinker and, at the same time, produce concrete that is durable. "Greener" concrete also improves air quality, minimizes solid wastes, and leads to sustainable cement and concrete industry.

3.6.1. Effect of Waste Paper on the Environment. The burning of waste paper has an impact on the environment which releases air pollutants into the atmosphere. Burning the printed paper released large amount of air pollutants than the nonprinted one. This might be due to the extra pollutant such as $\mathrm{CO}_{2}$ and oxides of nitrogen released by the printing ink. In addition, heavy metals such as $\mathrm{Pb}$ and $\mathrm{Cd}$ were found on ash of burned papers that could be mixed with soil. $\mathrm{Pb}$ and $\mathrm{Cd}$ are among toxic heavy metals that result in detrimental health effects. They lead to inhibition of the synthesis of hemoglobin and adversely affect the central and peripheral nervous systems, and the kidneys would be affected by $\mathrm{Pb}$. Cd adversely affects several important enzymes; it can also cause painful osteomalacia (bone disease) and kidney damage. Inhalation of cadmium oxide dusts and fumes results in cadmium pneumonitis characterized by edema and pulmonary epithelium necrosis (death of tissue lining of the lungs). Besides, using the waste paper as a cement replacement material provides double benefits. The first one is keeping environmental quality, and the other one is that it can be used as a cement replacement material in concrete production. Figure 3 shows how paper could affect the environmental quality.

3.6.2. Effect of Cement Production on the Environment. Portland cement is not environmentally very friendly. As good engineers, we must reduce its use in concrete. We must use more blended cements, especially with supplementary cementitious materials. The use of blended cements not only allows for a reduction in the energy used and reduced GHG emissions in clinker production but also is a mainly good- looking, efficient selection and right match up to a decrease in carbon dioxide giving out in calculations as well. The cement consumption and production are closely related to construction activity. Therefore, the environmental issue is the main concern because cement is the best significant concrete material wide-reaching. The cement industry utilizes a large amount of natural resources and energy. The cement industry and its associations have an obligation to improve environmental performance by improving the use of natural resources and reducing its overall energy consumption. Extracting raw materials to produce large amount of cement causes serious environmental problems and depletion of natural resources.

3.6.3. Raw Material Saving. Cement manufacture is a highvolume process. Typical average consumptions of raw materials for the production of cement are indicated in Table 20 .

The production of one ton of Portland cement required approximately 1.46 tons of raw materials are shown in Table 21 .

3.6.4. Consumption of Raw Materials in Concrete. Using waste paper pulp ash, which is a recycled material, will save raw materials. In concrete production, only the virgin materials are included. Therefore, utilizing the recovered materials (i.e., waste paper pulp ash), the amount of raw materials used in concrete will be saved.

Results in Table 22 show that using waste paper pulp ash as a cement replacement saves raw materials used in concrete. The $5 \%, 10 \%$, and $15 \%$ replacement saved about $0.66 \%$, $1.33 \%$, and $1.99 \%$ of raw materials, respectively, when compared to the control mix, which are about $15.55 \mathrm{~kg} / \mathrm{m}^{3}$, $31.1 \mathrm{~kg} / \mathrm{m}^{3}$, and $46.65 \mathrm{~kg} / \mathrm{m}^{3}$ respectively.

The use of waste materials and a wise use of natural resources will improve environmental impact and reduce carbon dioxide emission and natural raw material extraction from quarries. Concrete containing waste paper pulp ash is an example of sustainable construction development being feasible with satisfactory performance, in terms of both safety and serviceability of structures, at lower costs and with environmental benefits over ordinary concrete. Moreover, when using waste paper appropriately, some important properties of the hardened concrete such as compressive strength and durability can be better engineered. Utilization of waste paper as a cement replacement material in the concrete manufacturing industry has the following advantages:

(i) Improves the properties of concrete

(ii) Reduces the cost of concrete

(iii) Conserves natural resources (Raw Materials)

(iv) Reduces the amount of waste sent to landfills and incinerates

(v) Prevents pollution by reducing the need to collect new raw materials

(vi) Saves energy 

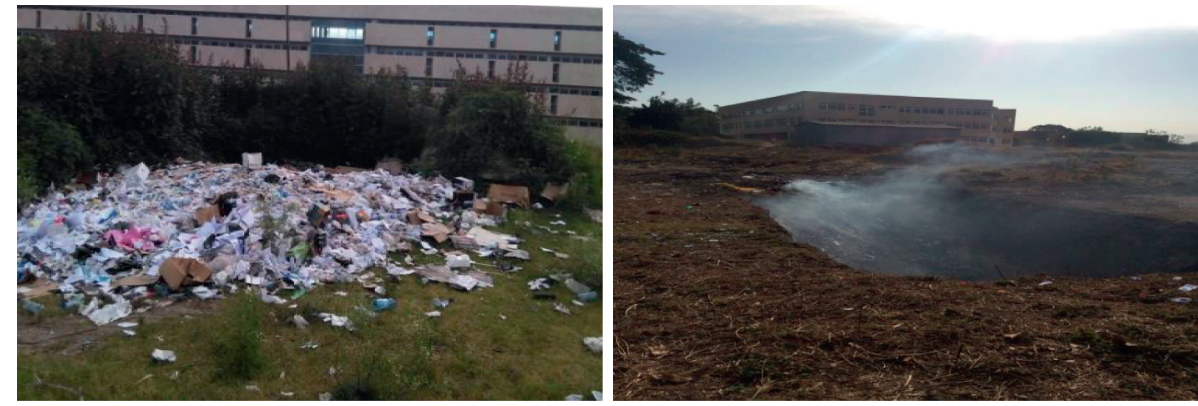

Figure 3: Waste paper dumped in the environment from offices and incinerated.

TABLE 20: Consumption of raw materials in cement production in tones [20].

\begin{tabular}{lc}
\hline Materials (dry basis) & Per ton cement \\
\hline Limestone, clay, shale, marl, and others & 1.27 \\
Gypsum and anhydrite & 0.05 \\
Mineral additions & 0.14 \\
Total raw materials & 1.46 \\
\hline
\end{tabular}

TABLE 21: Raw material saving in one ton of cement production.

\begin{tabular}{lcccc}
\hline Percentage of replacement & $0 \%$ & $5 \%$ & $10 \%$ & $15 \%$ \\
\hline Total raw materials & 1.46 & 1.39 & 1.31 & 1.24 \\
Saving of raw materials (\%) & 0 & 4.79 & 10.27 & 15.07 \\
\hline
\end{tabular}

Replacing $5 \%, 10 \%$, and $15 \%$ of cement by waste paper pulp ash will reduce $4.79 \%, 10.27 \%$, and $15.07 \%$ of raw materials, respectively.

TABLE 22: Raw material input for one cubic meter of concrete.

\begin{tabular}{lcccc}
\hline Mix code & WPPA0 & WPPA5 & WPPA10 & WPPA15 \\
\hline OPC $\left(\mathrm{kg} / \mathrm{m}^{3}\right)$ & 311 & 295.45 & 279.9 & 264.35 \\
WPPA $\left(\mathrm{kg} / \mathrm{m}^{3}\right)$ & 0 & 15.55 & 31.1 & 46.65 \\
Water $\left(\mathrm{kg} / \mathrm{m}^{3}\right)$ & 188 & 188 & 188 & 188 \\
Coarse agg. $\left(\mathrm{kg} / \mathrm{m}^{3}\right)$ & 1006 & 1006 & 1006 & 1006 \\
Fine agg. $\left(\mathrm{kg} / \mathrm{m}^{3}\right)$ & 839 & 839 & 839 & 839 \\
Total $\left(\mathrm{kg} / \mathrm{m}^{3}\right)$ & 2344 & 2344 & 2344 & 2344 \\
Virgin mat. $\left(\mathrm{kg} / \mathrm{m}^{3}\right)$ & 2344 & 2328.45 & 2312.9 & 2297.35 \\
Saving $(\%)$ & 0 & 0.66 & 1.33 & 1.99 \\
\hline
\end{tabular}

(vii) Reduces greenhouse gas emissions that contribute to global climate change

(viii) Helps to sustain the environment for future generation

\section{Conclusions}

(i) The normal consistency for blended pastes of OPCWPPA and PPC-WPPA was increased for all percentages of cement replacement, but initial and final setting time and the slump value of all concrete mixes decreased with the increase of waste paper pulp ash content.

(ii) The compressive strength result of the OPC-WPPA concrete mix with $5 \%$ cement replacement by waste paper pulp ash was better than that of the control concrete and reduced in $10 \%$ and $15 \%$ replacement of cement, but there is no compressive strength result improvement in all percentage replacements of PPC-WPPA concrete mixes.

(iii) The average density of each mixture of OPC-WPPA and PPC-WPPA concrete decreases. However, there were increases in the percentage of water absorption of OPC-WPPA and PPC-WPPA concrete with an increase in waste paper pulp ash content.

(iv) The maximum mass and compressive strength loss for both OPC-WPPA and PPC-WPPA concrete mixes were obtained with $0 \%$ of cement replacement in $2 \%$ sulfuric acid cured for a period of up to 28 days, whereas the minimal mass and compressive strength loss was with $15 \%$ replacement, which provides a higher resistance to sulfuric acid attack. This indicates the OPC-WPPA and PPC-WPPA concrete mixes with waste paper pulp ash replacement have a higher resistance to $2 \%$ sulfuric acidic environment.

(v) Burning or incinerations of waste paper and emission of particulates and gases into air from cement industry affect the environment. The potential gases emitted during burning waste papers are $\mathrm{CO}, \mathrm{CO}_{2}, \mathrm{SO}_{2}$, and NOx. Not only air pollutants but also heavy metals $(\mathrm{Pb}$ and $\mathrm{Cd}$ ) on ash of burned assessment papers could be mixed with soil. Main pollution of cement productions include extensive power consumption, cement dust, air pollution, water pollution, odors, solid waste pollution, noise pollution, environmental heating, ground vibration, and resource depletion due to raw material extraction.

(vi) Waste paper pulp ash saves cost and raw materials used in cement production and concrete. The 5\%, $10 \%$, and $15 \%$ replacement saved about $4.79 \%$, $10.27 \%$, and $15.07 \%$ per 1 ton of cement production and $0.66 \%, 1.33 \%$, and $1.99 \%$ per $1 \mathrm{~m}^{3}$ of concrete production, respectively, when compared to the control mix, which are about $15.55 \mathrm{~kg} / \mathrm{m}^{3}, 31.1 \mathrm{~kg} /$ $\mathrm{m}^{3}$, and $46.65 \mathrm{~kg} / \mathrm{m}^{3}$, respectively [21].

\section{Data Availability}

Some or all data, models, or code that support the findings of this study are available from the corresponding author upon reasonable request. 


\section{Conflicts of Interest}

The authors declare no conflicts of interest regarding the publication of this paper.

\section{Acknowledgments}

First and foremost, the authors' deepest thanks go to the Almighty God, as He did much and He is always with them. The authors are deeply indebted and very glad to express their sincere gratitude and appreciation to their advisor Dr. Bahiru Bewket for his important and constructive comments and professional advices and doing all these on time from the beginning of the proposal writing to the completion of this thesis.

\section{References}

[1] S. H. Kosmatka, B. Kerkhoff, and W. C. Panarese, Design and Control of Concrete Mixtures, Portland Cement Association, IL, USA, 2003.

[2] N. Zainudeen and J. Jeyamathan, Cement and its Effect to the Environment: A Case Study in Srilanka, pp. 1408-1416, Department of Bulding Economics, University of Moratuwa, Moratuwa, Srilanka, 2004.

[3] Ministry of Environment and Forest (MoEF), Facilitating Implementation and Readiness for Mitigation (Firm) Project in Ethiopia, p. 78, UNEP DTU Partnership, Copenhagen, Denmark, 2015.

[4] M. Amberber and Y. Addis, "Paper burning and associated pollution problems in higher educational istitutions of Ethiopia: the need and potential for recycling," International Journal of Wine Research, vol. 7, 2017.

[5] Food and Agriculture Organization of the United Nations, Forest Products, pp. 144-221, FAO, Rome, Italy, 2018.

[6] I. N. Gorgis, H. M. Zaki, and S. A. Salih, "Properties of Papercrete," ARPN Journal of Engineering and Applied Science, vol. 12, no. 24, pp. 7400-7412, 2017.

[7] A. O. Clement, "Properties of ceiling boards produced from a composite of waste paper and rice husk," International Journal of Advances in Science Engineering and Technology, vol. 4, no. 1, pp. 117-121, 2016.

[8] O. M. okeyinka and O. J. Idowu, "Assessment of the suitability of paper waste as an engineering material," Engineering, Technology \& Applied Science Research, vol. 4, no. 6, pp. 724-727, 2014.

[9] A. E. Al-Salami and R. M. Salem, "Preparation of waste paper fibrous cement and studing of some physical properties," Civil and Environmental Research, vol. 8, no. 3, pp. 42-54, 2016.

[10] V. Niranjan and S. Kanchana, "Studies on the compressive strength of cement mortar partially replaced with paper sludge and cover burnt bricks," International Journal of Trend in Research and Development, vol. 4, no. 1, pp. 542-545, 2003.

[11] Technical Association of the pulp paper Industry, Ash in Wood Pulp Paper and Paperboard: Combustion at $525^{\circ} \mathrm{C}$, TAPPI, GA, USA, 2002.

[12] ASTM. (C-618-78), Standard Specification for Coal Fly Ash and Raw or Calcined Natural Pozzolan for Use as a Mineral Admixture in Concrete, ASTM, PA, USA, 2017.

[13] Ethiopian Standard, ES 1176-3,4, \&5, ES 1177-1, \& ES 1178: Methods of Testing Cement, Quality and Standards Authority of Ethiopia, Addis Ababa, Ethiopia, 2005.
[14] A. Tagnit-Hamou, R. Gagne, A. Yahia, and S. Laldji, Characteristics of Wastepaper Sludge Ash and its Potential Applications in Concrete, University De Sherbrooke Canada, Sherbrooke, Canada, 2009.

[15] ASTM C-39, Standard Test Method for Compressive Strength of Concrete Specimens, American Concrete Institute, MI, United States, 1999.

[16] D. Abebe, Construction Materials Laboratory Manual, Addis Ababa University Printing Press, Addis Ababa, Ethiopia, 2002.

[17] S. P. Raut and S. A. Balwaik, "Utilization of waste paper pulp by partial replacement of cement in concrete," International Journal of Engineering Research in Africa, vol. 1, no. 2, pp. 300-309, 2017.

[18] ASTM. (C-642), Standard Test Method for Density, Absorption, and Voids in Hardened Concrete, ASTM, PA, United State, 2021.

[19] S. Goyal, M. Kumar, D. S. Sidhu, and B. Bhattacharjee, "Resistance of mineral admixture concrete to acid attack," Journal of Advanced Concrete Technology, vol. 7, no. 2, pp. 273-283, 2009.

[20] M. Stajance and A. Estokova, Environmental Impacts of Cement Production, Technical University of Kosice: Lviv Polytechnic National University Institutional Repository, Kosice, Slovokia, 2012.

[21] ACI 211.1-91, Standard Practice For Selecting Proportions For Normal, Heavyweight, And Mass Concrete, ACI Committee, MI, USA, 1991. 